\title{
The petroleum industry in the Netherlands - its setting and possible future
}

\author{
L.D. Alblas ${ }^{1,2}$ \\ Corresponding author; Email: 1dalblas@wirehub.n1 \\ 2 Independent consultant
}

Manuscript received: May 2000; accepted in revised form: 19 Dec 2000

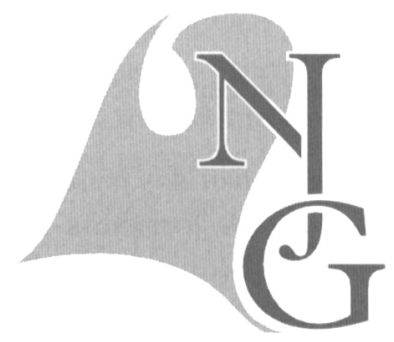

\begin{abstract}
The setting and possible future of the petroleum industry in the Netherlands is briefly discussed. The result of a risk assessment shows, that the Dutch hydrocarbon province can be divided in low, medium, high and very high-risk areas for new capital investments. The assets of operators in the Netherlands have been evaluated on exploration, production, storage and pipeline potential, now and in the future. Despite the presence of potential new plays, exploration activities are expected to decrease in the near future. Despite the possible development of marginal fields, which will be not adding major reserves, the production reserves will decrease in the next $10-15$ years and many fields will be abandoned. However storage, pipeline infrastructure and gas marketing are expected to increase in the future, mainly because of the liberalisation of the Dutch gas market.
\end{abstract}

Keywords: Dutch hydrocarbon province, exploration plays, marginal fields, production infrastructure, risk assessment, operators, future energy market.

\section{Introduction}

Some 40 years after the discovery of the 'Groningen Field' and many subsequent discoveries, both onshore and offshore, it is opportune to present a review of the increasingly mature position of the Dutch E\&P industry and possibilities for future developments.

Figure 1 provides an overview of the overall Dutch hydrocarbon province: onshore only the existing fields, offshore existing fields and pipelines.

Exploration in new blocks is becoming less successful, as shown by the recent history: so far the 8 th round exploration results are discouraging, because only one production license has been filed, which later has been withdrawn. The first results of the 9th round exploration blocks are not encouraging either. However, operators exploring in or close to currently producing blocks, are in a more favourable position than operators in isolated blocks: existing infrastructure in the vicinity of new small discoveries allows developments of those discoveries in an economic way.

Production from on- and offshore Dutch fields has been established from several reservoirs, of which the Rotliegend Sandstone reservoir - the productive gas reservoir of the Groningen field - is the main one. Many of the productive fields in the Dutch hydrocarbon province are close to or in a declining production phase.

Many companies facing decreasing oil and/or gas production have to decide either to sell their Dutch interests or to extend their existence by changing the scope of their E\&P activities by evaluating other opportunities. Such opportunities may include gas storage, gas transport and gas marketing.

In the future, smaller sized companies and indepen- 
dents, operating on lower overhead, may have the opportunity to enter the Dutch market and produce so-called marginal oil and gas fields or take-over oil and gas fields with declining production.

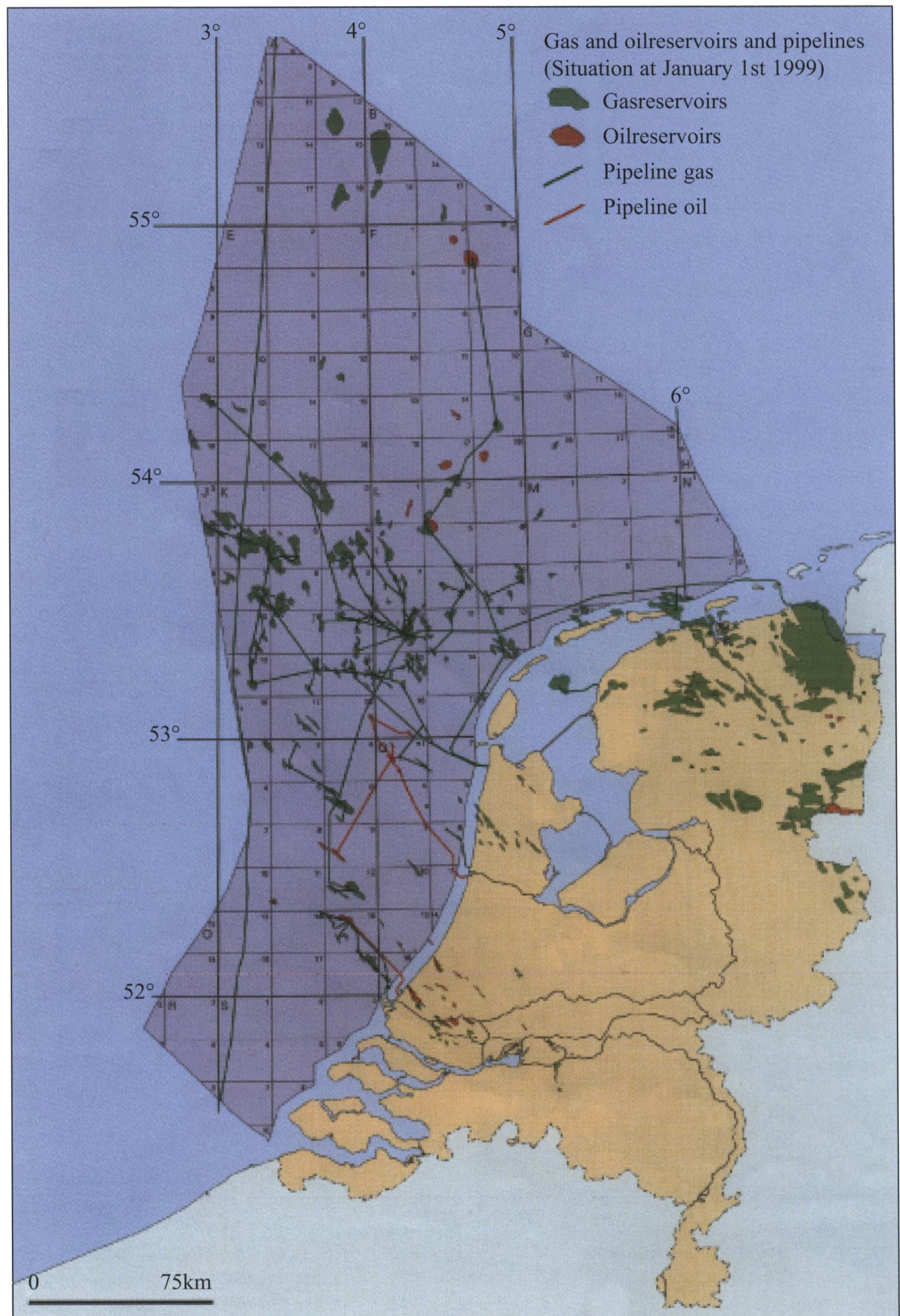

Figure 1. Gas and oil reservoirs and pipelines, situation at January 1st 1999 (After Oil and gas in the Netherlands exploration and production, 1999). 


\section{Historical summary}

After the discovery of the Groningen Field in 1959, several foreign companies, interested in exploring oil and gas, entered the Netherlands. In case of economically successful exploration operators usually followed up with production operations, often including transport pipelines to export gas and/or oil from the producing fields.

In the mid eighties, this pattern started to change: Pennzoil, an American operator, had established gas production and was still active in exploration. However, after gas production had peaked this company sold its Dutch interests. In the late eighties British Petroleum (BP) sold its Dutch interests as result of rearrangement of its portfolio: better opportunities in other parts of the world were preferred. Lately, BP again acquired E\&P interests in the Netherlands through the take-over of Amoco. In the early nineties Conoco stopped exploring and went in harvest mode with its oil assets and in the late nineties their production interests were sold to Clyde Petroleum. Placid, in a package deal, sold its interests to CanOxy, which later sold its Dutch interests to TransCanada.

\section{Exploration Plays}

Figure 2 presents an overview of the Dutch stratigraphy (EZ, 1999; Van Adrichem Boogeart \& Kouwe, 1993). It shows that several productive oil and gas reservoirs are present, both onshore and offshore. Main reservoirs for gas are the Permian Rotliegend Sandstone and the Triassic Buntsandstein Sandstone (Glennie, 1990; Oele et al., 1981). Other gas reservoirs are the Carboniferous (Bless et al., 1977) Jurassic (Wong et al., 1989), Cretaceous (Van den Bosch, 1983), Tertiary Sandstones (Duyverman et al., 1991) and Zechstein Carbonates (Van Adrichem Boogeart \& Burgers, 1983).

The main source rocks for this gas are the Carboniferous coals.

For oil, the main reservoirs are the Jurassic-Cretaceous Sandstones (Bodenhausen et al., 1981; Burgers \& Mulder, 1991; Herngreen \& Wong, 1989; Herngreen et al., 1991; Van Wijhe, 1987). The main source rock for this oil is the Posidonia Shale from the Jurassic Altena Fm, although Carboniferous oil source rock potential cannot be excluded.

With respect to trapping of hydrocarbons, the Zechstein and Triassic salts form the seals for the main producing reservoirs. Other seals are Röt Shales, Cretaceous Shales, Rotliegend Shales and possibly Zechstein anhydrite.
The last few years some new hydrocarbon plays have been discovered in offshore areas: a Chalk oil play in the northern part of the Dutch sector on the edge of the Central Graben basin (Ziegler, 1990), where Posidonia Shale, the oil source rock of Jurassic age, is present. This successful discovery will possibly come on stream in the years $2000-2001$.

Another play is a Triassic Buntsandstein oil and gas play in the southern part of the Dutch sector. This play was discovered outside the West Netherlands Basin, far away from the Jurassic source rock. From publications and regional well information a Carboniferous source rock is inferred, while Lower Cretaceous shales form the seal for this play. Unfortunately it turned out that this play is not yet economically viable: a production license application has been withdrawn. However, this discovery indicates a new trend, which likely may be tested in the future.

Furthermore many undeveloped marginal fields are present in the on- and offshore Netherlands, which potentially could be of economic interest.

In view of the mature character of the Dutch hydrocarbon province, it is likely that future discoveries will be of very small to small or at best medium size, unless the new plays prove to be more prolific than presently considered (Rondeel et al., 1996).

\section{Risk evaluation for investments in the Dutch hy- drocarbon province}

In this paper a model will be presented to assess the risk for capital investments in the mature Dutch hydrocarbon province, based on prospectivity of the area on one side and the risk related to production operations on the other side.

The prospectivity concerns undeveloped discoveries, known prospects, unexplored areas and new plays. This is based on publicly available well and seismic data, scout information, publications and reports.

With respect to risk on the production side it is important to establish whether fields under consideration are situated in areas with a declining production, a plateau production, a build-up production or in areas without infrastructure. Especially for the very small to medium fields short distance to existing facilities and availability of spare capacity in the treatment/export system determine, whether development of such fields can be made economic by tie-ins.

These aspects reflect the risk associated with prospectivity (potential new developments) and the risk associated with establishing production facilities (spare capacity, tie-ins and new construction). 


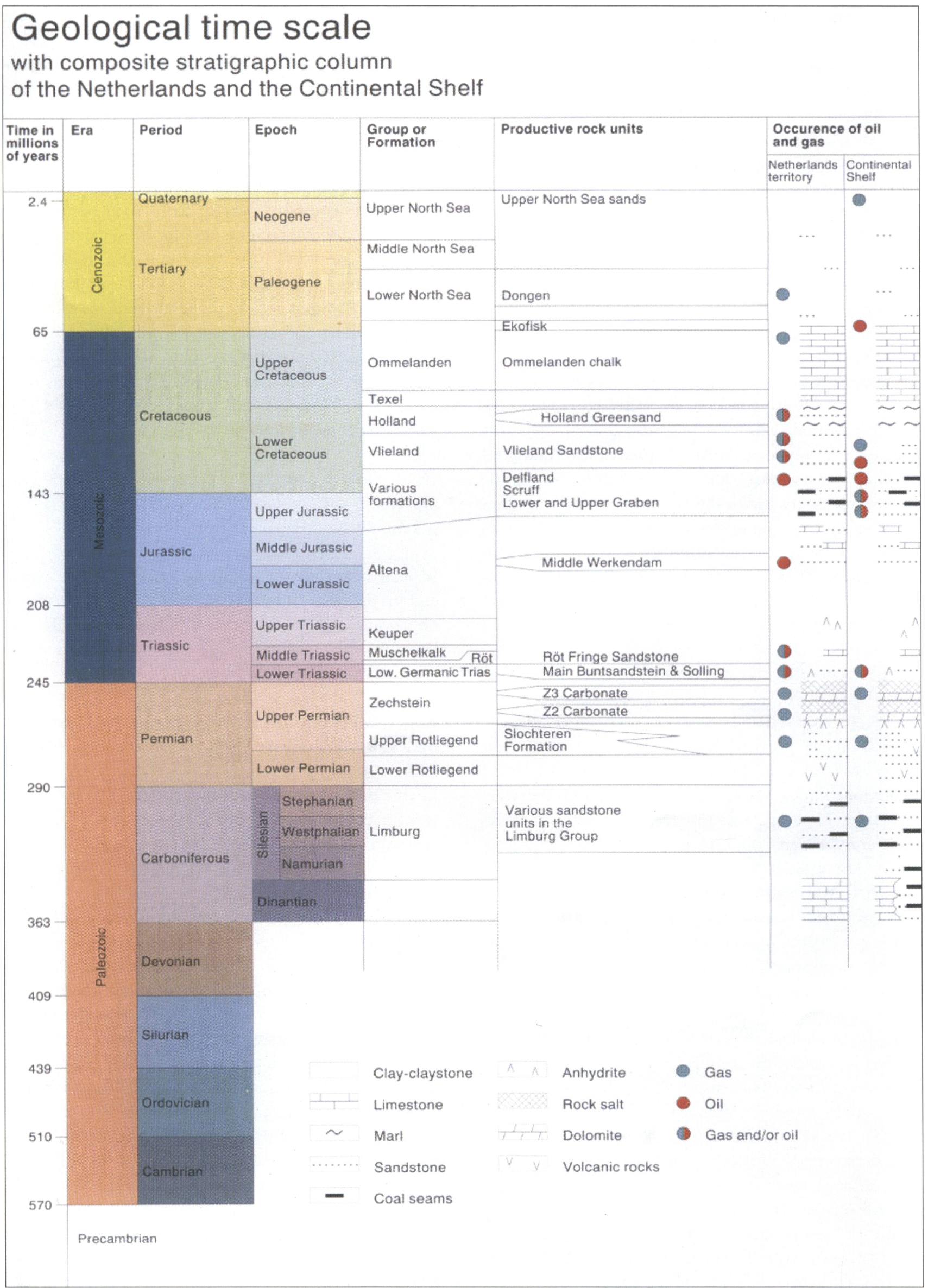

Figure 2. Geological time-scale of the Netherlands (After Oil and gas in the Netherlands exploration and production, 1999). 
The result of this assessment is, that the Dutch hydrocarbon province can be divided in areas with low, medium, high and very high-risk for new capital investments e.g. individual wells, field developments with more wells or export facilities.

Figure 3 presents an overview of the low, medium, high and very-high risk areas.

The areas are defined as follows:

A) Low risk:

Fully developed area in the decline or plateau phase, where spare capacity is available.

Undeveloped oil and gas discoveries (marginal fields) are present.

Good prospectivity for new discoveries, new discoveries can easily be tied-in.

B) Medium risk:

Fully developed area in the plateau or build-up phase.

Undeveloped oil and gas discoveries (marginal fields) present.

Prospectivity for new discoveries.

C) High risk:

Area in plateau, build-up phase.

Undeveloped oil and gas discoveries (marginal fields) present.

Prospectivity of area not well defined .

D) Very High risk:

No infrastructure present or close by.

No undeveloped discoveries or known prospects. Prospectivity not well defined and speculative.

Apart from the above-mentioned factors any future development of marginal fields is also depending on economic parameters and innovations in drilling and production techniques. Economic parameters include estimated oil and gas prices, production treatment and transport cost. In addition to innovative production and drilling techniques, non-conventional usage of oil and gas could be decisive for the decision to proceed with development of e.g. offshore electricity production, offshore production of methanol or other easily transportable liquids.

In the low risk area the main plays are the Rotliegend gas play and Buntsandstein oil and gas play, with additional Carboniferous, Zechstein, Jurassic and Cretaceous oil and gas plays.

In the medium risk area, the main plays are the Buntsandstein and the Tertiary gas plays and the Jurassic and Cretaceous oil plays, with additional Zechstein oil or gas play.

In the high-risk area, the Carboniferous gas play is the main play with additional Namurian, Rotliegend, Zechstein, Buntsandstein, Cretaceous and Tertiary oil and gas plays.

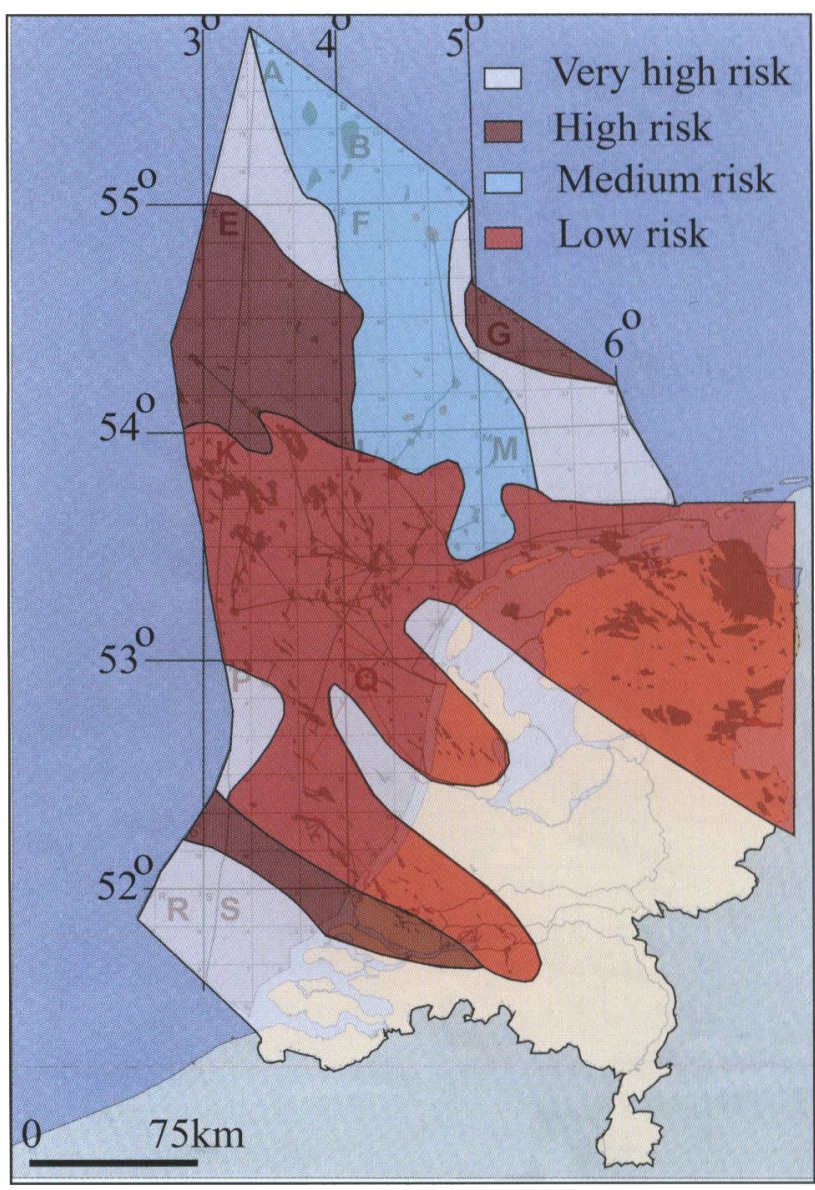

Figure 3. Risk assessment of the Dutch hydrocarbon province (L.D. Alblas, 1999).

In the very high-risk area potential Devonian, Carboniferous, Rotliegend, Zechstein, Buntsandstein, Cretaceous and Tertiary gas plays are present.

\section{Operators present in The Netherlands}

\section{Activity overview}

In the Netherlands the following operators $(1 / 1 / 99)$ are active:

In offshore operations a key factor is the accessibility or ownership of pipelines to bring oil and gas to shore and to on-shore pipeline or storage systems. This will in the future allow lining up with the international pipeline infrastructure in the UK, Norway, Germany, Russia, etc.

In the Netherlands the main company transporting and marketing gas is Gasunie, owner of a well-developed distribution network including pipelines for export of gas to various countries. In the future this network will even more be interlinked to pipeline networks of other countries and this will allow import of gas from other producing areas. 
Table 1. Operators active in The Netherlands $(1 / 1 / 99)$.

\begin{tabular}{lllll}
\hline Gas Operators & Exploration & Production & Storage & Pipelinesw/Landfall \\
\hline Amerada Hess & $\mathrm{x}$ & & & \\
Century & $\mathrm{x}$ & $(\mathrm{x})$ & & \\
Veba & $\mathrm{x}$ & $\mathrm{x}$ & & \\
Elf & $\mathrm{x}$ & $\mathrm{x}$ & & \\
Clyde & $\mathrm{x}$ & $\mathrm{x}$ & & $\mathrm{x}$ \\
Unocal & $\mathrm{x}$ & $\mathrm{x}$ & & $\mathrm{x}$ \\
Chevron & $\mathrm{x}$ & $\mathrm{x}$ & $\mathrm{x}$ & $\mathrm{x}$ \\
Wintershall & $\mathrm{x}$ & $\mathrm{x}$ & $\mathrm{x}$ & $\mathrm{Pipelinesw/Landfall}$ \\
TransCanada & $\mathrm{x}$ & $\mathrm{x}$ & Storage & \\
BpAmoco & $\mathrm{x}$ & Production & & \\
NAM & Exploration & $\mathrm{x}$ & & $\mathrm{x}$ \\
\hline Oil Operators & & $\mathrm{x}$ & & \\
\hline NAM & & $\mathrm{x}$ & & \\
Clyde & & & & \\
Unocal & & & & \\
BpAmoco & & & & \\
\hline
\end{tabular}

In the following discussion the position of the individual operators will be reviewed and ranked with respect to exploration and production potential.

\section{Amerada Hess}

Amerada Hess (only exploration) is operator of one exploration block in the most northern part of quadrant A in the Dutch offshore. The area is classified as very high risk, the potential prospectivity is not well defined. No infrastructure is present in the area. On this very high-risk exploration block a well was drilled, but a potential Jurassic Sandstone play was encountered dry.

\section{Century}

Century (only exploration) has only one exploration block in quadrant $\mathrm{E}$ in the northern part of the Dutch offshore. The area, where the block is situated, is classified as high risk. The play is Carboniferous gas with a possible upside of gas in Rotliegend Sandstone. So far there have been no drilling activities to test this play.

\section{Veba}

Veba (only exploration), which until recently was a non-operating company in the Netherlands, has become operator by acquiring the RWE-DEA interests in the Netherlands. RWE-DEA had been operating several exploration blocks in the Dutch offshore. These exploration licenses are situated in the $P$ and $F$ quadrants. Also, before Veba acquired the RWE-DEA interests, RWE-DEA successfully tested a new play in the northern F quadrant: a Chalk oil play. In the southern part of the Dutch offshore, in the P quadrant, Veba is also partner in a block, where an oil and gas discovery was made. Although a production license application was withdrawn for this discovery, it could indicate a new oil trend in the area. In the $9^{\text {th }}$ round the adjacent block was acquired. The general area of this block is ranked as low risk.

Furthermore Veba will develop the acquired RWEDEA's oil discovery in the $F$ quadrant in the northern part of the Dutch Offshore. This area is ranked as medium risk.

Table 2 . Summary for companies with exploration only

\begin{tabular}{llll}
\hline & $\begin{array}{l}\text { Very } \\
\text { high risk }\end{array}$ & $\begin{array}{l}\text { High } \\
\text { Risk }\end{array}$ & $\begin{array}{l}\text { Medium/ } \\
\text { Low Risk }\end{array}$ \\
\hline $\begin{array}{l}\text { Amerada } \\
\begin{array}{l}\text { Century } \\
\text { Veba }\end{array}\end{array}$ & $\mathrm{x}$ & $\mathrm{x}$ & \\
\hline
\end{tabular}

\section{Elf}

Elf's (exploration \& production) main production licenses in the offshore are concentrated in the K\&L quadrants and in the $\mathrm{F}$ quadrant. In the K\&L quadrants, Elf produces gas from the Rotliegend and from some Carboniferous reservoirs. In the F quadrant, gas production is coming from the Triassic Buntsandstein.

Onshore Elf's production is concentrated in the northern part of the Netherlands. Gas production is mainly from Rotliegend and Cretaceous Sandstones. Some gas production is coming from the Cretaceous Chalk. Currently Elf's gas production potential is ranked high and will be medium in the future.

Elf's offshore exploration blocks are mainly concentrated in the $B \& F$ and in the $E \& G$ quadrants. The main potential reservoirs are the Carboniferous and Triassic Buntsandstein, with additional Rotliegend, 
Zechstein, Jurassic and Cretaceous plays. Onshore Elf has exploration blocks in the very high-risk area, with some Carboniferous, Rotliegend and Triassic Buntsandstein potential. Elf's exploration potential is ranked as low. The future expectation is, that Elf will continue with development drilling in its production blocks.

Elf does not operate a pipeline network and in case it has aspirations to go in gas marketing in the Netherlands, it will have to acquire pipeline infrastructure.

Clyde

Clyde's (exploration \& production) main gas production licenses in the offshore are concentrated in the $P \& Q$ quadrants. Clyde's gas production is mainly coming from Rotliegend, Triassic Buntsandstein, and Zechstein reservoirs. A few years ago, Clyde acquired Conoco's interests in oil producing fields in the $\mathrm{K} \& \mathrm{~L}$ quadrants, just north of the $Q$ quadrant. The oil producing reservoirs are Jurassic and Cretaceous Sandstones.

Onshore, Clyde has gas production from the Triassic Buntsandstein. This gas production is situated in a low risk area.

The gas production potential of Clyde is currently medium ranked and will be low in the future.

The oil production is ranked as low. In the future the oil and gas production are ranked low.

Clyde's offshore exploration licenses are mainly situated in the $P \& Q$ and the G\&M quadrants. The main potential reservoirs in the low and medium risk areas are the Rotliegend and Triassic Buntsandstein with additional Carboniferous, Zechstein, Jurassic and Cretaceous plays. Onshore, Clyde has exploration acreage with some Triassic Buntsandstein potential. This acreage is situated in the high-risk area.

Clyde's exploration potential is currently ranked as medium, but will be trending to a low status in the near future. Clyde announced a discovery in the northern $Q$ quadrant, situated in the low risk area of the Dutch offshore.

Apart from a small size pipeline from their $Q$ quadrant gas fields to the "Hoogovens" steel factory, Clyde does not have any significant pipelines with landfall.

\section{Unocal}

Unocal (exploration \& production) is mainly an oil producer. The producing blocks are concentrated in the northern part of the $Q$ quadrant. The main oilproducing reservoir is the Cretaceous Sandstone. Unocal also has gas production from the Rotliegend in its oil producing blocks. Unocal has stopped its exploration activities, because of the company's view of remaining potential in the Netherlands.
The production of Unocal is currently ranked as medium. In the future the production potential is ranked as low, many oil fields are in or close to end life status. In the future the then inactive oil pipeline could possibly be used for gas transport.

\section{Chevron}

Chevron (exploration \& production) has only one production license, onshore in the northern part of the Netherlands. This production license is situated in a low risk area. The main gas-producing reservoir is the Rotliegend. The production is ranked low; the field is at end live status.

Chevron does not have exploration licenses. If technically viable, there could be a possibility to evaluate if this field can be used for gas storage.

\section{TransCanada}

TransCanada (exploration \& production), originally a downstream company, acquired the pipeline infrastructure, exploration and gas production interests from CanOxy in the Netherlands. The offshore production licenses are concentrated in the $\mathrm{K} \& \mathrm{~L}$ quadrants. The main gas-producing reservoir is the Rotliegend. TransCanada does not have any onshore production.

The gas production is ranked medium, but will be low in the future.

Offshore TransCanada has an exploration license in the $G$ quadrant in the medium risk area. The potential reservoir is the Triassic Buntsandstein.

On the exploration side TransCanada has some potential left in its production and exploration licenses. Exploration potential is ranked medium, but will be low in the future.

The pipeline infrastructure could be of interest in the future: Transcan currently is operator of the Noordgas Transportline (NGT), which lately has been extended to the UK border.

\section{Wintershall}

Wintershall (exploration \& production) is a gas producer and has offshore production licenses in the $P$, $\mathrm{K}, \mathrm{L}$ quadrants and the $\mathrm{D}$ quadrant. In the $\mathrm{P}, \mathrm{K}, \mathrm{L}$ quadrants, the low risk area, the main gas-producing reservoir is the Rotliegend. In the $\mathrm{D}$ area, the highrisk area, the gas-producing reservoir is the Carboniferous. Wintershall has established gas production from the Carboniferous. Its Rotliegend reservoirs are expected to be depleted in the near future. Current production is ranked medium, but will be low in the near future.

The offshore exploration blocks are situated in Q\&L quadrants, the low risk area, the B \& F quad- 
rants, the medium risk area and the $\mathrm{D} \& \mathrm{E}$ quadrants, the high-risk area. The potential reservoirs are the Carboniferous, Rotliegend, Zechstein, Triassic Buntsandstein, Jurassic, Cretaceous and Tertiary. Wintershall does not have any onshore exploration licenses.

The exploration potential is ranked medium, despite their 9 th round efforts. In the future exploration potential is ranked as low.

Lately, Wintershall has announced to connect the German A6/B4 discovery (north to the Dutch offshore) with a pipeline to NAM's F3 infrastructure (in the northern part of the $\mathrm{F}$ quadrant), to tie-in to the Nogat pipeline to Den Helder (about $50 \mathrm{~km}$ north of Amsterdam).

Although Wintershall is operator of the WestGas Transportline (WGT), the company is seen as an upstream company. However in the future it has the possibility to enter downstream activities, like gas marketing by extending this pipeline to the UK or line up with the Norfra pipeline.

\section{BpAmoco}

BpAmoco (exploration, production and storage) does not have any exploration licenses on- or offshore the Netherlands.

BpAmoco's only exploration potential is concentrated in its production licenses on- and offshore and is ranked low. Currently and in the future no more exploration activities are to be expected, besides some possible appraisal drilling in the on- and offshore production licenses.

BpAmoco's gas production licenses offshore are situated in the $\mathrm{P}$ quadrant. The main producing reservoir is the Triassic Buntsandstein. The onshore production license is situated just north of Amsterdam. The gasproducing reservoir here is the Rotliegend.

BpAmoco has high gas production potential, but this will be decreasing in the near future to a low production potential. Offshore oil production stopped, because of severe technical problems with its produc-

Table 3. Summary of companies with exploration \& production.

\begin{tabular}{llllll}
\hline & \multicolumn{2}{l}{ Present } & \multicolumn{2}{l}{ Future } \\
\cline { 2 - 3 } \cline { 5 - 6 } & Expl. Pot. & Prod. Pot. & & Expl. Pot. & Prod. Pot. \\
\hline Elf & $\mathrm{L}$ & $\mathrm{H}$ & $\mathrm{L}$ & $\mathrm{M}$ \\
Clyde & $\mathrm{M}$ & $\mathrm{M}$ & $\mathrm{L}$ & $\mathrm{L}$ \\
Unocal & $\mathrm{L}$ & $\mathrm{M}$ & $\mathrm{L}$ & $\mathrm{L}$ \\
Chevron & - & $\mathrm{L}$ & & - & - \\
TransCanada & $\mathrm{M}$ & $\mathrm{M}$ & $\mathrm{L}$ & $\mathrm{L}$ \\
Wintershall & $\mathrm{M}$ & $\mathrm{M}$ & $\mathrm{L}$ & $\mathrm{L}$ \\
\hline
\end{tabular}

$\mathrm{L}=$ low potential, $\mathrm{M}=$ medium potential, $\mathrm{H}=$ high potential. tion wells. Also an application for the production of oil in an area adjacent to their offshore gas production acreage was withdrawn.

With respect to its pipeline infrastructure, BpAmoco has a gas pipeline with landfall in the Europoort area, west of Rotterdam. There is a possibility to extend this pipeline in the near future to the UK, or to line up with the Norfra pipeline.

Also BpAmoco operates an oil pipeline with landfall in the Europoort area. Currently this pipeline is only used for condensate transport from its gas fields, however, this pipeline could be used in the future for oil transport from possible marginal oil fields, which could be developed in the Dutch offshore near BpAmoco's infrastructure.

BpAmoco has one gas storage project, situated in Alkmaar area, just north of Amsterdam. There is an opportunity to extend gas storage in the future: offshore gas storage in its production blocks in the $\mathrm{P}$ quadrant and extending the storage capacity in The Alkmaar area. However, extending the storage capacity in the Alkmaar area might have a severe environmental impact, because of recent tremors in the Alkmaar area, caused by gas production.

\section{$N A M$}

NAM's (exploration, production \& storage) exploration licenses are spread all over the Dutch on- and offshore, covering all possible plays. Main exploration plays are the Rotliegend, Triassic Buntsandstein and Tertiary, but also Carboniferous, Zechstein, Jurassic and Cretaceous.

NAM's exploration potential is ranked as high. Mainly, because of their potential Waddenzee reserves in an area, which is environmentally very sensitive. Lately, the government has decided to delay the permission to drill in the Waddenzee area.

NAM has production licenses on- and offshore. Onshore the production licenses are mainly concentrated in the northern part of the Netherlands. The main producing reservoir is the Rotliegend, but also there is production from the Carboniferous and Zechstein. The offshore production licenses are concentrated in the $\mathrm{K}, \mathrm{L}, \mathrm{Q}, \mathrm{M}$ quadrants, and the low risk area, but also in the $F \& G$ quadrants, the medium risk area. The main gas-producing reservoir is the Rotliegend, but there is also gas production from the Carboniferous, Triassic Buntsandstein and Jurassic.

Oil production is coming from Cretaceous Sandstones in the low risk area in the west of the onshore Netherlands.

The current production (NAM is also operator of 
the Groningen field) is ranked as high. In the Dutch offshore there are several discoveries pending to be developed. In the future the production potential is ranked as high.

NAM has two gas storage projects with the possibility to increase the capacity in the future: the Grijpskerk gas storage, situated in the Groningen area and Langeloo gas storage, situated south of the Groningen field in the northern part of the Netherlands.

\section{Gas marketing activities in the Netherlands Gas marketing activities in the Netherlands}

The main company, which for many years had all the gas marketing activities in the Netherlands, is Gasunie. Gasunie is for $50 \%$ owned by the Nederlandse Aardolie Maatschappij.

However, in light of the liberalisation of the Dutch gas market, other companies with downstream activities will have the possibly to enter the Dutch market and be competitive with Gasunie. The expectation is, that Gasunie will lose some of its market share in the future. At this moment, there are already other companies delivering gas to consumers in the Netherlands. Two examples: through the interconnector from the UK to consumers in the southern part of the Netherlands and there is a Norwegian company delivering gas to a power station in Delfzijl, Groningen, situated in the area of the Groningen gas field.

Gasunie has also plans to connect its onshore gas pipeline system with the international infrastructure: a plan was initiated to connect Den Helder to Bacton in the UK, early the next century.

\section{Future of the Dutch oil and gas industry}

As already mentioned many of the productive reservoirs in the Dutch on- and offshore are in a declining stage. Many companies, facing the decrease of their oil and/or gas production have to decide to sell their Dutch interest or to extend their existence by evaluating other opportunities. These opportunities are gas storage, gas transport and gas marketing. In light of the liberalization of the Dutch gas market more companies with gas marketing activities will enter the Dutch market. There are already other companies delivering gas to consumers in the Netherlands.

Remaining exploration and production potential in the Netherlands is situated in the high-risk area. Small reserves are still present in the low and medium risk areas. High-risk plays are the Namurian oil and gas plays and Devonian Sandstone gas plays in the most northern and southern part of the Dutch offshore. In the future some more gas discoveries will be made in the Carboniferous, Rotliegend, and Triassic, although no major reserves are to be expected.

On the production side, there are the undeveloped marginal oil and gas fields in the Dutch offshore. Other examples are the undeveloped Carboniferous gas discoveries in the northern part of the Dutch offshore, situated in the high-risk area, where no infrastructure is available. Another example is the undeveloped and abandoned oil discoveries in the offshore part of the southern Dutch North Sea. In this area infrastructure is available and these fields could have the possibility to be developed. This development could be an opportunity for smaller sized companies and independents to enter the Dutch market and to produce these marginal oil and gas fields or take-over declining production from major oil companies.

\section{The future energy market of the Netherlands}

Despite the figures mentioned in Oil and Gas in the Netherlands (EZ, 1999), of future gas potential of $210-430 \times 10^{9} \mathrm{~m}^{3}$ in the Netherlands, the expectation is, that there will be a decrease in exploration activities in the Dutch on- and offshore.

As already mentioned there are still the possibilities of Carboniferous, Rotliegend and Triassic gas plays and possible high-risk Namurian and Devonian plays and also the development of some marginal oil and gas fields.

But production in the Netherlands (other than Groningen field) will be decreasing in the next 10 to 15 years and many fields will be abandoned.

Despite the opportunity for smaller sized companies

Table 4. Summary of companies with exploration, production and storage.

\begin{tabular}{|c|c|c|c|c|c|c|}
\hline & \multicolumn{3}{|l|}{ Present } & \multicolumn{3}{|l|}{ Future } \\
\hline & Expl. Pot. & Prod. Pot. & Stor. & Expl. Pot. & Prod. Pot. & Storage \\
\hline NAM & $\mathrm{H}$ & $\mathrm{H}$ & $\mathrm{H}$ & $\mathrm{H}$ & $\mathrm{H}$ & $\mathrm{H}$ \\
\hline BPAmoco & $\mathrm{L}$ & $\mathrm{H}$ & $\mathrm{M}$ & $\mathrm{L}$ & L & $\mathrm{M}$ \\
\hline
\end{tabular}

$\mathrm{H}=$ high potential, $\mathrm{M}=$ medium potential, $\mathrm{L}=$ low potential 


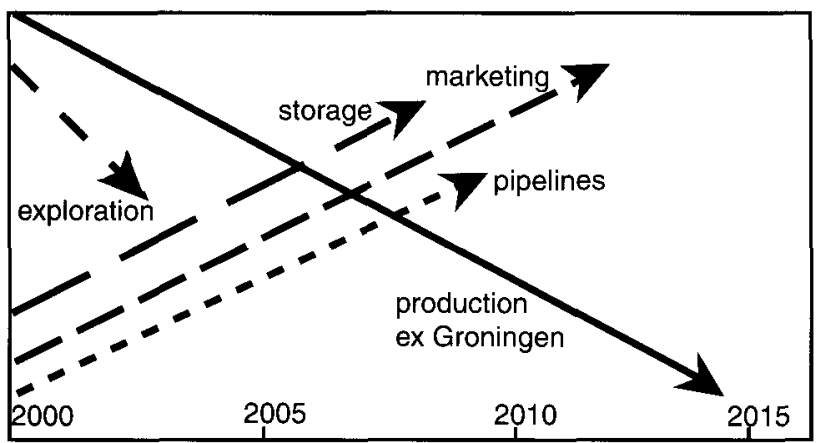

Figure 4. The future energy market of the Netherlands (L.D. Alblas, 1999).

and independents, to produce the marginal oil and gas fields, production from these fields will be only in the order of only $5-10$ years and will not be adding major reserves in the future.

However, there is the expectation of an increase in storage, pipeline infrastructure and gas marketing in the future, this mainly because of the liberalisation of the Dutch gas market.

In Figure 4, the expectation of the exploration, production, storage, pipeline infrastructure and gas marketing in the future has been plotted.

\section{References}

Bless, M.J.M., Bouckart, J., Claver, and M.A. \& Paproth, E., 1977. Paleogeography of the Upper Westphalian deposits in NW Europe with reference to the Westphalian $C$ North of the mobile Variscan Belt. Med. Rijks geol. Dienst 28-5: 101-147.

Bodenhausen, J.W.A. \& Ott, W.F., 1981. Habitat of the Rijswijk oil province, onshore, The Netherlands. In: Illing, L.V. \& G.D. Hobson (eds.) Petroleum geology of the continental shelf of NW Europe- Institute of Petroleum, London: 301- 309.

Burgers, W.F.J. \& Mulder, G, G., 1991. Aspects of the late Jurassic and early Cretaceous history of the Netherlands. Geol. En Mijnbouw, 70: 347-354.

Duyverman, H.J., Geil, K., Michelsen, O. \& Sørensen, K., 1991.
Tertiary geology and prospectivity of the Netherlands' northern offshore. Paper presented at the Eur. Ass. Petroleum Geosc. Conference at Florence. No EO21.

Glennie, K.W., 1990. Lower Permian - Rotliegend -. In: Glennie, K.W. (ed.): Introduction to the Petroleum geology of the North Sea. Blackwell SC. Publ., Oxford: 120-52.

Herngreen, G.F.W. \& Wong, Th.E., 1989. Revision of the 'Late Jurassic' stratigraphy of the Dutch Central North Sea Graben. Geol. en Mijnbouw, 68: 73-105.

Herngreen, G.F.W., Smit, R. \& Wong, Th.E., 1991. The stratigraphy and tectonics of the Vlieland basin, the Netherlands. In: Spencer, A.M.(ed) Generation, accumulation and production of Europe's hydrocarbon. Eur. Ass Petroleum Geosc., Eng. Spec.Publ. 1: 175-192

EZ., 1999. Olie en Gas in Nederland opsporing en winning/Oil and gas in the Netherlands exploration and production. Ministry of Economic affairs, The Hague.

Oele, A.C.J.P., Hol, J.A. \& Tiemens, J., 1981. Some Rotliegend gas fields of the K and L blocks, Netherlands offshore (1968-1978) - a case history -. In: Illing, L.V. \& Hobson, G.D. (eds.): Petroleum and continental Shelf of North-West Europe: 289-300.

Rondeel, H.E., Batjes, D.A.J. \& Nieuwenhuijs, W.H. (eds.), 1996. Geology of Gas and Oil under the Netherlands: 284pp.

Van Adrichem Boogaert, H.A. \& Kouwe, W.F.P., 1993. Stratigraphic nomenclature of the Netherlands; revision and update by RGD and NOGEPA. Med. Rijks Geol. Dienst 50.

Van Adrichem Boogaert, H.A. \& Burgers, W.F.J., 1983. The development of the Zechstein in the Netherlands. Geologie en Mijnbouw 62: 83-92.

Van den Bosch, W.J., 1983. The Harlingen Field, the only Cretaceous gasfield in the Upper Cretaceous Chalk of the Netherlands. Geologie en Mijnbouw 62: 145-156.

Van Wijhe, D.H., 1987a. Structural evolution of inverted basins in the Dutch offshore. Tectonophysics 137: 171-219.

Van Wijhe, D.H., 1987b. The structural evolution of the Broad Fourteens Basin. In: Brooks, J. \& K.W. Glennie (eds) Petroleum Geology of Northwest Europe. Graham \& Trotman, London: 315-323.

Wong, Th.E., van Doorn, Th.H.M. \& Schroot, B.M., 1989. 'Late Jurassic' petroleum geology of the Dutch Central North Sea Graben. Geologische Rundschau, 78: 319-336.

Ziegler, P.A., 1990. Geological Atlas of Western and central Europe. (Second edition) Shell International Petroleum Mij., The Hague: 239 pp, 56 encls. 